\title{
The Meaning of Life
}

\author{
Richard Swinburne
}

[Swinburne, Richard, 2016, "The Meaning of Life" in (ed.) S.Goetz and J.Seachris The Meaning of Life, Bloomsbury Academic.]

My concern in this paper will be with the meaning of the lives of humans on earth before death; if, as I believe, there is life after death, that will be relevant to my discussion only insofar as its character affects the meaning of life before death. The question of what is the meaning of life can be understood in many ways, the most obvious of which are: 'What purpose did anyone have in making humans?', 'Which states of affairs or actions would give meaning to human lives?', and 'Which states of affairs or actions do humans believe would give meaning to their lives?'. I shall ignore the third question, as it is clearly one for social psychologists to answer. The first question would take us into the whole issue of whether there is a God who created and sustains us and what he is like; and I shall not seek to answer that question here. But I shall argue here that the answer to it is relevant to the second question which is surely the one being asked by most of those who wonder about whether life has a meaning. And what the question seems to be getting at is: 'What would make a life worthwhile, or good to have lived?', and I shall understand it thus. I shall answer the question by appealing to intuitions which I believe almost all of us already have. I shall consider initially what would be worthwhile in our life on earth if we ignore the possible existence of God and a life after death; and then proceed to consider what difference would be made to the worthwhileness of our life on earth if there is a God and life after death.

Many kinds of states of affairs and actions are good; and any enumeration of them must begin with enjoyment. It is good to be in a state of affairs where you desire (or in the modern sense, 'want') to be, to have the feelings, desires, and beliefs which you desire to have, and to be doing an action which you desire to be doing - this is equivalent to enjoying being thus situated or doing that action. A person is happy insofar as on balance he is so situated or doing such actions. This may or may not involve sensations of pleasure - thrills or warm feelings - but, if a person has those, they are part of what makes their action or situation enjoyable. But there is an obvious 
kind of qualification to be put on this. Someone who is getting his enjoyment from having feelings of hatred or other bad feelings, or from false beliefs or from doing what is morally wrong is not having or doing something which contributes to a worthwhile life - whether or not he realizes that he is having bad feelings or doing , (objectively) what he is doing is something morally wrong. Indeed getting enjoyment in these ways is worse than not getting enjoyment at all. But, subject to this kind of qualification, surely all states and actions which are enjoyed are good because they are enjoyed, and so I side with those who think that if Sisyphus were injected with a drug which makes him enjoy endlessly pushing a stone up a hill, then that is a good state of affairs ${ }^{1}$ - though of course there are better ones. And more generally, I suggest that (with some exceptions) the better the state of affairs in which one enjoys being or feeling, or the better the action one enjoys doing, the better is the state of enjoying it. Blessed is the person who not merely helps others but enjoys doing so.

Yet as most people recognize, there is more to a worthwhile life than enjoyment. There are states of affairs in which it is good to be whether or not you enjoy them as - despite his professed utilitarianism - Mill recognized in his famous sentence, 'It is better to be a human being dissatisfied than a pig satisfied; better to be Socrates dissatisfied than a fool satisfied'. ${ }^{2}$ These states include both internal and external states. The former are involuntary states of oneself, often involving a relation to something outside oneself; the latter are states outside oneself which affect one. It is good for us to have power to make a difference to ourselves and the world, above all if we have some libertarian freewill, so that it is up to us to choose how to exercise our power independently to some extent of the influences acting on us. It is good if our power includes some power over what happens to others, that is that we have responsibility for others. It is a blessing for us to need and to have children and friends whose well-being depends on us, and to desire to help them. To be no use to anyone is tragic. It is also good for us to have others such as parents, a spouse, and friends who know about our needs and can forward our well-being and desire to do so, for that makes it possible for them to be involved in our life in a deep way.

It is good to have true beliefs and correct feelings. It is good to have true beliefs (which I shall call simply 'knowledge') about anything but especially about what is intrinsically good or bad, and about the causes of intrinsically good or bad states, and more generally about deep moral, metaphysical, aesthetic and scientific matters (which may be obtained by appreciation of literature and other arts, as well as by studying rigorous philosophical arguments.) It is good to have good desires - for the well-being of all humans 
(and animals), and especially of those close to us, and of ourselves hence the goodness of Mill's human who desires to know more, and so is 'dissatisfied'. It is a good to have correct feelings - of sympathy for those suffering, of affection for those friends who have interacted with us in important ways over a long time (parents and children, among others), of grief at the deaths of such friends, of sorrow at the failure of their projects, of anger at wrongdoers, and of respect for all humans - especially for the good and wise and powerful. It is good to feel respect for all humans for what is good in them, and so especially for the morally good, but also for those who have great power and responsibility - since having these is good in us, it is good in anyone else - so long as they exercise their power wisely. It is good to be well situated externally - to live in a beautiful city, or a law-abiding and prosperous country. For many of us our lives are worthwhile in many of these respects.

But it is basic intuition that what we do with our powers and especially what we do successfully contributes more to the worthwhileness of our life than what happens to us.All actions as such - so long as they are not for bad goals - are, I suggest, goodfor it is good to be the cause of things. But actions are better, the more their goals take time and energy to achieve; it is as such good to have and fulfil a project. And it is better, the better the goal; while actions with bad goals are bad. I shall henceforward use the adverb 'morally' in a wide sense so as to call any action which is overall good 'morally good'; and any action which is overall bad 'morally bad'. The morally good actions will therefore include obligatory actions (i.e. duties); and morally bad actions will include wrong actions, those which are obligatory not to do. Obligatory actions include feeding and educating our children, caring for our parents, keeping promises, telling the truth (possibly subject to qualifications), and expressing our gratitude to our benefactors. Wrong actions include breaking promises, lying, murdering, maiming, raping and so on. Morally good actions also include the best actions of all, supererogatory actions, actions 'beyond the call of duty', actions of doing more than we are obliged to do - caring for the parents and educating the children of others, and sacrificing one's own life (not merely some time and energy) to save the life of someone else. Morally good actions will also include 'creative acts' ${ }^{3}$ fulfilling some project in no way obligatory or supererogatory, which involves effort and patience; and such an action is better, the better objectively is the goal of the project. Any acquisition of new knowledge or powers is good, but it is better the more important is the topic of knowledge, or the area of the power. It is better to study the origins of Buddhism than to list different types of beer label; better to learn an ancient language than to invent a new language for the former saves an ancient culture from oblivion and honours its 
members. It is very good too to write novels, poems and plays; play music, and paint pictures, and develop one's understanding of the moral, metaphysical, and aesthetic realities - even if solely for our own benefit. But it is surely in general more important to fulfil an obligation than to do a supererogatory good act, and clearly more important than to do a creative act. Morally bad actions include ones which are not wrong, and which I call infravetatory. It is wrong to rape or steal, yet it is bad but not wrong to watch many low grade thrillers on TV rather than read one or two great works of literature. And surely in general it is more important not to do what is wrong than not to do what is infravetatory. Almost all feelings which it is good to have, and situations in which it is good to be, are such that it is good to share them with others. It is better to get the sensations of sexual pleasure through the development of a personal relationship, not by themselves. Almost all actions which are good to do are better to do in cooperation with others. It is better to drink alcohol in company than alone. It is good for siblings to work together to look after parents, good to work with others to save a decaying waterway or an ancient language.

We have special obligations to those to whom we owe much, and especially to our parents who are to some small degree the cause of our existence, and - if they are also nurturing parents - for all their actions of feeding and nurturing us. We have special obligations to spouses who have promised us their lifelong loyalty; and special obligations to children whom we have caused to exist in an initial condition of total impotence. And we have lesser obligations to those who have benefited us in lesser ways, including simply by cooperating with us at work or having a friendly conversation with us. It is especially good for us and them if we benefit them spontaneously and supererogatorily; and - as many writers have stressed - long lasting personal relationships are central to a worthwhile life.

If we do wrong to others, it is obligatory to make atonement. Making atonement has four parts, not all of which are needed in the case of serious wrongs. We must repent, apologise, make reparation; and do something extra to 'make up' for the wrongdoing, which I call a 'penance'. ${ }^{4}$ And it is good, if we make atonement, for the person wronged by us to forgive us (i.e. to resolve to treat us in the future as though we had not wronged them), though in my view not obligatory to do so.

The goodness of all these actions is an objective goodness, which exists whether or not the agent realizes that they are good; and objectively our lives would be much more worthwhile insofar as we do these actions. It is good in the case of many of these actions if we do them spontaneously - helping those in need for example because they are in need. But it is also good if we force ourselves to 
do the action despite a contrary desire, just because it is morally good to do - good for us, though not as good for those we seek to help. Yet of course no one action can be both spontaneous, and also done with difficulty for moral reasons. Not all our attempts to do good actions succeed, but it is good to have tried - good for those we tried to benefit, and good that someone tried to benefit them. It is good too if we tried to benefit them, and good that we tried to learn a foreign language, even if we failed. This is because trying is itself an action; and it is good that such an action should be directed towards a good end. We are exercising our powers in pursuit of the good. 'Better to have loved and lost than never to have loved'. But of course even better to have loved and won; successful actions contribute much more to the worthwhileness of a life than unsuccessful actions.

So in summary, a life of enjoyment, enriched by acquisition of knowledge and right feelings and deep friendships is worthwhile, and we can make it much more worthwhile by helping others to enjoy themselves, acquire knowledge, right feelings and abilities.

So far in considering what makes a worthwhile life, for humans on earth before death, I have not taken into account the difference which would be made by our relation to anything transcendent. There is only space to consider the difference which would be made by one possibility, that there is a God who has the properties and has done the actions described in the Christian creeds. In this section I shall ignore the claim that God will give us a life after death, and consider that only in the following section. My conclusion will be that if there is a God of the kind described in the Christian creeds our situation would be far better than it would be otherwise, but that we have the power to make it both a lot better still or very much worse than it would be otherwise. Our life has a cosmic significance, good or bad, instead of a significance very limited in time and space. As before, I am describing the objective situation which would exist if there is a God, whether or not we realize it.

The Christian religion teaches that the whole universe and all its inhabitants including ourselves were created and are sustained by God who loves each one of us. I claimed in the previous section that it is a great good to have some understanding of the nature of things. The existence of God and his interaction with us makes available to us a deeper understanding of the ultimate nature of things than we would have otherwise. For -even if we cannot understand why there is a God, at least we can understand why 
there are laws of nature and why humans exist -because God made and sustains them because he seeks to bring about good states of affairs. I claimed in the previous section that it is good for us to have others who know all about our needs and can forward our wellbeing. If there is a God, he knows all our needs and seeks to meet them in the best way. For so many humans, there is no other human who knows very much at all about their pains and pleasures; and, I suspect, there is no human whose pains and pleasures are fully known by any other human. Anyway human friends die; but if there is a God, he keeps in his memory all the details of our significant and insignificant private and public lives. And we have the power to ask him (in prayer) to do good things for us and for others; and if it is good that he should grant our requests he will do so. I noted earlier that it is good to feel reverence for the great who are also good, and to feel gratitude to benefactors. If there is a good God who made us, it is therefore very good to have the right feelings of enormous reverence for the supremely good and ultimate source of things and great gratitude for our own existence and all the good things our life contains. If there were no God, there would be no one to whom to be grateful for our existence - for although your parents may have chosen to have a child, they could not have chosen to have you. While it is good for us to have some good thing, it is always better if the good thing is given in an act of love for us. So it is very good for us if our whole life does not come to us by chance but by the act of a loving creator.

The very existence of God makes new actions obligatory or otherwise good; and we can make our life much more worthwhile by doing these actions. Whether or not we feel gratitude and reverence, we have an obligation to show the proper attitude towards God in grateful worship, and to cultivate those proper feelings. And it is supererogatorily good to do these things to a greater extent than we are obliged to do. Further, the mere existence of God makes acting morally always more important and sometimes very much more important than it would otherwise be. For we owe it to God not to waste the life he has given us, but to use it in good ways, as (to a much smaller degree) we owe it to our parents (if they are nurturing as well as biological parents) not to waste our life. So it is obligatory to fulfil our human obligations for a reason additional to the reason that we owe it to others to do so; and good too to benefit them in supererogatory ways, for a reason additional to the reason that it is good for them that we should do so. Further, other humans (and indeed animals) are, like ourselves, God's creatures - and so in a sense our brothers and sisters; and so our obligations to them are much stronger then they would be otherwise. And if we harm them we harm their creator, God - just as if I hurt your child, I wrong not merely the child but also you who have languished your love on her. 
And since each of us is God's creature, we have an obligation to God (although not to ourselves - an obligation is a debt; and one cannot have a debt to oneself) to care for ourselves. So, even without any commands issued by God, our scope for doing good or bad becomes much greater if there is a God, and so too therefore does the meaningfulness of our life if we choose the good.

But Christianity also teaches that God has issued particular commands, and that these impose new obligations on us. Benefactors often lay down a condition for the use of their gift. I may give a sum of money to one of my children on condition that they use it to buy a house. They are not obliged to accept the gift on that condition, but if they do accept it they have an obligation to fulfil the condition. Sometimes however the recipient of a gift subject to a condition is not able to understand the condition. Parents who are not just biological parents, but are nurturing and educating parents, give a lot to their children. And although they would not think of themselves as giving nurture and education to their children subject to a condition, they do expect and society expects them to expect that in return the children will do certain things for them, both when the children are young and when the parents are old. When children are young, parents command them to do certain things - e.g. to do the family shopping - and the command creates an obligation which would not otherwise exist. And when the parents are old, the children have an obligation to care for them. Since the children who receive so many good things from their parents were in no position to accept or reject them, they are rightly - in virtue of the goodness of the gifts - presumed to have accepted them, and to have accepted the obligations which accompany acceptance of the gift.

Parents are our greatest earthly benefactors. But God, for the reasons I have just discussed, is an incomparably greater benefactor. Hence our obligations to him are incomparably greater. Although he is never in the position of aged parents, we are in effect for all our life in the position of young children, totally dependent on him, having from him the good gift of life itself while originally being in no position to choose whether or not to accept that gift. (Yet I hesitate to mention it - we are normally able subsequently able to reject the gift by committing suicide) Hence God's commands, like the commands of a parent, impose upon us obligations to do what he commands, obligations which would not otherwise exist. The Book of Genesis pictures God as creating man and telling him how to use his life - 'Be fruitful and multiply', 'Fill the earth and subdue it', but do not eat of the tree of the knowledge of good and evil. And all Western religions claim that God has issued in the course of time more specific commands, among them the 'Ten Commandments'. That we should obey God's commands is the condition under which he gives us life; and we who have used the life he gave us for many years 
must accept the condition under which we have been given it. God's commands make it contingently the case that some action which would otherwise be only supererogatorily good or morally indifferent is now obligatory; and his forbidding it makes an action morally wrong, when previously it was only infravetatorily bad or morally indifferent. And the teaching of Jesus has filled out for us how God commands us to live. While endorsing the obligations captured in the 'Ten Commandments' and other obligations which secular morality recognizes - e.g. 'render into Caesar the things which are Caesar's' which in the context of its utterance implies 'pay your taxes', he clearly regarded God as having commanded all humans to do more and more demanding actions of kinds which, but for God's command, would be merely supererogatory - such as giving food to the hungry, drink to the thirsty, welcoming the stranger, clothing the naked, and visiting the sick and those in prison. ${ }^{6}$ And he commands particular individuals to fulfil their own often difficult vocations, such as spreading the Gospel in particular places (such as his command to Jonah to preach to the people of Nineveh the need for repentance. In issuing commands of these kinds to particular individuals God entrusts the fulfilment of his purposes to them; and thus, not merely do we need God, but God has put himself in a position where he needs us. I argued earlier that it is a good thing to be needed; it is a very good thing to be needed by the creator of the universe in the fulfilment of his greatly good purposes for humans. The new obligations which I acquire if there is a God are obligations to do greatly worthwhile actions; and the existence of God and his commendations provide great scope for further supererogatory good acts. It is good to render praise in supererogatory ways to God for creating and sustaining us; and good to visit the sick and those in prison more than we are obliged to do. These acts are not merely good for the sick and those in prison, but good for God who created us to do such good acts and thereby forward Christ's Kingdom of love on earth, and also good for us.

In all these ways, the existence and commands of God make it possible for us, not merely to do more and more important good acts, but thereby to form a good character. For each time we do a good act, it becomes easier to do a good act next time. As Aristotle remarked, 'we become just by doing just acts, prudent by doing prudent acts, brave by doing brave acts. ${ }^{7}$ So by doing such acts, we may make it natural to do them, and so come to enjoy doing them.

But of course we may fail and waste our lives; and then we must apologize not merely to any wronged humans but also to God, who made us to be good and whose children the wronged humans are. While it is bad for me if my life is wasted, it is worse if I am the cause of the waste, but not so bad if compensation is available for the waste of the life or my wasting it. If there is no God, there is no 
compensation available either for the waste of my life or for my wasting it. Christianity however teaches that Jesus Christ, God Incarnate, died on the cross to provide a reparation (and penance) which we can offer back to God with our repentant apology in atonement for our sins, that is our wrongs against him; and if we do, he will forgive us - subject to the condition that we forgive those who have wronged us. And for that atoning act of Jesus we owe immense further gratitude to God. Forgiving someone who has wronged you involves treating them as though they had not wronged you, and so you compensate the wrongdoer for the badness of their action (though not its consequences). Many of us have wasted our lives in many ways. If my life is a gift from God and I have wasted it, then I owe God repentance for having done so and he can forgive me and so treat me as though I have not wasted my life. My wasted life was not mine to waste - I owed it to God to lead a good life, and soby my wasting my life, it is God, not I, who has lost something. By forgiving me, God will remove the badness of my wasting my life. Only a religion with a creator God offers the possibility of compensation for the badness of my wasting my life. And God can remove the bad consequences of my wasting my life.

And while I owe my life in small part to my parents, and I owe it to them as well as to other humans whom I have harmed to repent and apologise, and also to make reparation. If I do repent, apologise, and make such reparation as I am able to make, to those other humans, God provides a considerable incentive to them to forgive me, even without adequate reparation - since God's forgiveness of them is conditional on their forgiveness of me. Nevertheless, even if others forgive me for having wronged them, the bad consequences of my action may remain; if I have maimed them or even killed them, I cannot undo this damage - but God can. In most cases God has given them so much good anyway that the harm they have suffered at my hands is already compensated by the good life which he has provided for them so far; but sometimes the harm which I have caused them may outweigh the good aspects of their lives; and God can help here too - and I will come to this point shortly.

So the existence and actions of God, on the Christian an account of these, makes our situation on earth more worthwhile than it would be otherwise, and gives us enormous scope to make it yet far more worthwhile by doing morally good actions which have a deeper importance than they would have otherwise. But a God who creates morally free agents would surely not think it right to impose on them obligations which cover every moment of their lives. So I endorse the Catholic view ${ }^{8}$ in opposition to classical Protestantism, that there is a limit to the obligations which God imposes on humans. There is scope for 'works of supererogation' and also - I suggest - 
for 'creative acts', though we certainly would not need to do these in order to give meaning to our lives.

But, just as the existence of God opens up enormous possibilities for good not available otherwise, it also opens up enormous possibilities for evil. If we fail to worship, fail to fulfil God's commands, and fail to fulfil our ordinary secular obligations (which are now doubly obligatory), we do great wrong to our creator. And if we go on doing this, we become naturally bad people, and so people motivated to do actions less and less by the goodness of those actions, until eventually we become insensitive to moral considerations. We 'lose our souls', and become merely a theatre of competing desires. To lose the possibility of so much good would be a great evil.

\section{III}

Good as life on earth could be for all humans, especially if there is a God, even if he did not provide an after-life, it could be even better if, as Christianity claims, God provides an after-life for us. As in both the previous sections,I am describing the objective situation which would exist in this case if there is a God and an afterlife - whether or not we realise that.

I begin with one aspect of the teaching of Jesus about the after-life which has been given little consideration in the subsequent tradition - the possibility of a good (maybe temporary) after-life in compensation for suffering on earth. Some humans on earth are so racked with pain and ignorant of the possibilities of good action, that their earthly life is on balance barely good, and maybe even bad. Although their suffering may provide opportunities for others to help them, God as our benefactor must compensate those who suffer in this way. And God has it also in his power to compensate after death those whom I have hurt for the hurt which I have done to them when I cannot repair this and when he has not already compensated for it on earth. The parable of the rich man and Lazarus ${ }^{9}$ suggests that Jesus taught that a good state in the after-life is sometimes a compensation for a life of suffering on earth, rather than always being a reward for a life of virtue. On earth the rich man 'feasted sumptuously every day' while Lazarus 'longed to satisfy his hunger with what fell from the rich man's table'; but after death Lazarus 'is comforted', but the rich man is 'in agony'. There is no suggestion in the parable that Lazarus lived a particularly saintly life; what gained him the good after-life was simply his suffering on earth. The possibility of a good after-life as compensation for those who suffer too much on earth adds much to the worthwhileness of life on 
earth.That an after-life at least on balance good is available for reasons other than that they have lived a saintly life on earth was suggested by the medieval theory of Limbo, the place between Hell and Heaven which would be occupied by unbaptised.

However that may be, the central Christian doctrine of the after-life concerns the final separation of those who have lived good lives on earth from those who have lived bad lives. The former are promised heaven. The second Vatican Council declared that while 'salvation' and so Heaven was not open to those who had without justification rejected the Christian message, it was open to nonChristians (including atheists) so long as they have 'striven to live a good life'. In declaring this, the Council repeated the view of some of the most important Christian theologians of past centuries. ${ }^{11}$ It is open, that is, to those who have got into the habit of living a good life, and so would be ready to avail themselves of the atonement provided by Christ when they learn about it. The New Testament (apart from its last book, The Book of Revelation) has relatively little to say about what Heaven would be like; but some patristic and medieval theologians developed what it had to say, ${ }^{12}$ and I suggest the following as a reasonable account of the Christian view of this.

Christian theology emphasizes that the life of Heaven is something which begins on Earth for the person who pursues the Christian way. This is because the pursuit of that way on Earth involves starting to do the tasks of Heaven - which are the good actions described in the previous section - for a short time under difficult conditions. The Christian on Earth has begun to understand the divine nature (by Bible reading, receiving religious instruction, etc.), to worship (in the eucharist with music, poetry, art, etc.), and to show the divine love to others. But his tools are poor - his mind and his instructors provide weak understanding of the divine nature; his organs and choirs are poor things; and so often neither in worship nor private prayer does he feel in contact with God; other humans are hostile to his religion; his attempts to help others fail; and he often has strong desires to do bad actions. These obstacles to the full pursuit and enjoyment of the Christian way would be removed in Heaven. Those who have shown serious dedication to the good by persistently doing good actions on earth, would have no inclination to do evil when the obstacles to doing good are removed.

More precisely, the removal of earthly obstacles will mean growth in unclouded ${ }^{13}$ awareness of the nature of God himself, traditionally called the 'Beatific Vision' of God, and responding to it in grateful adoration and service. The Book of Revelation represents God as making his home among humans, and declaring 'I will be their God and they will be my children'. ${ }^{14}$ Since God is a being of infinite wonder, it can take beings of finite power an eternity to comprehend him. Those who 'follow the way of God's wisdom', wrote 
Origen, should think of themselves as living in tents, 'with which they always walk and always move on, and the further they go, so much more does the road still to walk grow long and stretch out endlessly .. [The mind] is always called to move on, from the good to the better, and from the better to still higher things' ${ }^{15}$ Heaven will also involve friendship with good finite beings, including those who have been our companions on Earth. The task of comprehending and worshipping God will be a co-operative one. Augustine wrote that the description of Heaven as 'the city of God' would have no meaning 'if the life of the saints were not social' ${ }^{16}$ Christian theology has always stressed both that Heaven will involve a renewal of earthly acquaintance, and that the enjoyment of such acquaintance will not be its main point. And of course one always enjoys acquaintance better if it serves some further point - if one and one's fellows are working together in a worthwhile task. The saints reign with Christ in glory, ${ }^{17}$ and so have other work to do - interceding before God for humans on earth or elsewhere, and executing God's purposes in other ways; and thus bringing others into the sphere of God's love. So the occupations of Heaven are simply the occupations which, I argued in the previous section, are the occupations which would be good on earth if the Christian doctrine of God is correct; but the occupant of Heaven will be able to pursue in a far fuller way without impediment. The inhabitant of Heaven would inevitably be greatly happy - for happiness consists in doing and have happen to you what you want to be doing and have happen to you. Aquinas taught that man's ultimate goal is beatitudo, ${ }^{18}$ which is not merely supreme 'happiness' but supreme happiness derived from doing successfully what is supremely worthwhile. And that is what the life of Heaven would be, when the obstacles to living the Christian life are removed, and so the blessed are successful in securing the vision of God so difficult to obtain on earth. The person who has the wrong character does not want to pursue the occupations of Heaven; and so, even if he got to Heaven, he would clearly not be happy there and so not have the well-being possessed by those who want to be there. So if there is a Christian God who also provides life after death, there is available to us on earth a meaningful life on earth, which has - among other goals - the goal of attaining that heavenly life, and which would make life on earth even more meaningful than it would be otherwise.

But of course the greater the goal, the greater the loss if we fail to secure it. And, given the availability of Heaven (which may for many of us, on Orthodox or Catholic views, require an intermediate and perhaps purgatorial period, in which we can make ourselves more fully dedicated to the good), we have the power on earth to deprive ourselves of an enormous good by finally rejecting it. Majority Christian tradition has emphasized that this can happen 
only by our own (what I reasonably construe as) 'libertarian' free choice (i.e. a choice not fully caused by anything else, be it God, nature, or nurture). And, in rejecting 'universalism' (the view that necessarily all humans will be saved, that is go to Heaven), it allows the possibility that someone will so frequently and seriously reject good choices that they lose all sense of moral goodness and so all inclination to do the good, and thus they will not be saved. Hell is the 'place' for such persons. There is, I suggest, no need to take talk of 'fiery' torture (poena sensus) too literally, but it will certainly - on Christian tradition - involve poena damni, the penalty of the loss of God, which Augustine, a firm advocate of everlasting sensory 'punishment' for the wicked, acknowledged as by far the most important part of the 'punishment' of Hell. ${ }^{19}$ But if God is really to give humans a choice of the kind of people they are to be, he must offer them the choice of rejecting him permanently; and allow them if they really insist on making that choice - to have what they choose $^{20}$. If there is a God and an after-life, we do indeed have the power to make our life very much better and also very much worse than it would be otherwise.

\section{IV}

What I have been describing in the previous sections is what I regard as the features of human life, both those features for which we are not responsible, and the actions which we can choose to do, which make it meaningful. In the first section I appealed to common intuitions about this; but in the two subsequent sections, I applied the results of the first section to show that life could be very greatly meaningful if we choose to do certain kinds of action - on the assumption that there is a God of the kind which Christianity postulates who will provide us with an after-life. I have not given arguments here for the latter assumptions - although I have given them at length elsewhere. ${ }^{21}$ But each of us can only do our subjective best - live the life which would be the best to live, given our own beliefs about what this is. If you believe my assumptions, then your subjectively best life would be what I have claimed to be the objectively best life. But suppose you are agnostic about these matters. Suppose you believe perhaps that it is as likely as not that there is a God and an after-life of the kind which Christian tradition claims, but suppose that you also believe that if any theistic religion is true, it is most probable that the Christian religion is true. What in that situation is the point of trying to live a Christian life? My answer is that living the Christian life could still be the subjectively best life for you to lead, because although it would consist in trying to reach 
goals which might well not be attainable, yet because those goals are such great ones, the attempt to attain them would give significant meaning to your life.

I begin by considering the part of that life which involves prayer and worship. Consider this analogy to your situation suppose that you are poor and badly need money, and then you learn that some anonymous person has put a large sum of money into your bank account which will enable you to satisfy your needs. You do not know who the donor is, but you think that it is as probable as not that it is a certain person, Smith. Surely, you would think it good (even if not obligatory) to thank Smith profusely, even though he refuses to acknowledge being the donor. You would think very badly of yourself if you had not made some serious attempt at gratitude not merely saying words of gratitude but doing some minor favour for Smith. If you are in the same position in relation to God, it would surely be good to make a similar attempt at expressing gratitude and trying to do one or two of the things which, if he exists, he would want you to do.

Secondly, while only the obligations towards your fellow humans would be subjectively obligatory for you, all the obligations towards your fellows which result from the existence of God and from the commands of God to do even more and more demanding actions of the same kind of thing (give more to the poor, help to educate those in more distant countries and so on) are ones which even secular morality recognizes as supererogatorily good. To live the best possible life involves doing much good beyond obligation.

So even as an agnostic, in order to live the subjectively best earthly life, you have good reason to try to live the Christian life. But for agnostics, even more than for theists, it's not easy to live that life on earth; and it would be good for you to live that life in a Heaven where there are no obstacles to its fulfilment. Yet you would only enjoy that sort of life in Heaven if you desire to live it, and the only way to get to desire to live there is to try to get into the habit of living it on earth when it is difficult. So, if you think that there is, say, a probability of $1 / 2$ that the Christian doctrinal system is true, and you want what it offers (that is, Heaven) a lot more than you want other things (and if my arguments so far are correct, it is good to want this), it would be good to live the Christian life on earth, especially since it is good anyway for other reasons to live that life. So for an agnostic, as for a Christian believer, the subjectively best life to live would be the Christian life. (But of course that conclusion does not follow if you believe that it is very improbable that Christian doctrines are true). It gives great meaning to life to seek a greatly worthwhile goal, even if there is a significant probability that you will not achieve it. 


\section{NOTES}

1. See Richard Taylor, Good and Evil, Macmillan, 1970, chapter 18.

2. J.S. Mill, Utilitarianism (1861), ed. M. Warnock, Collins, 1962, ch2.

3. For Susan Wolf (Meaning in Life, and why it Matters, Princeton University Press, 2010) such 'creative acts', as I call them, are central to what makes a life 'meaningful', although she holds that a life being meaningful also involves fulfilling one's 'duties' and being 'happy'.

4. See my Responsibility and Atonement, Oxford University Press, 1989 for full treatment of the concepts of atonements and forgiveness.

5. Genesis $1: 28$ and 2:17.

6. See Matthew 25:31-46.

7. Nichomachaean Ethics 1103b.

8. The line between the obligatory good acts (stated in 'precepts') and the supererogatory (stated in 'counsels') has been drawn in different places by different theologians. Aquinas, for example, saw the instructions about 'true love for enemies and the like' as precepts telling us that 'we should be ready to do good to enemies and so on when necessary demands'; but also as counsels to do this 'when no special necessity arises' - Summa Theologiae Ia2ae 108.4 ad 4.

9. Luke 16:19-31.

10. Vatican II. Dogmatic Constitution on the Church (Lumen Gentium) §16.

11. For example, see my Faith and Reason, second edition, Oxford University Press, 2005, p. 208 n.5.

12. See B.E. Daley, The Hope of the Early Church, Cambridge University Press, 1991. I am indebted to Daley for his very full description of the understanding of the after-life by Christian theologians of the first five hundred years of Christianity. He brings out how there is virtually total agreement among those theologians about the nature of Heaven, although there is much less agreement about whether there is a purgatorial state through which some have to pass on the way to Heaven, and about the fate of those (if any) who do not get to Heaven.

13. Thus Paul: 'Now we see in a mirror, dimly, but then we will see face to face' (I Corinthians 13:12).

14. Revelation 21:7.

15. Origen, Homily 17 on Numbers, cited in Daley, op. cit. p. 50.

16. City of God 19.5..

17. See Christ's words to his disciples: 'Truly, I tell you, at the renewal of all things, when the Son of Man is seated on the throne of his glory, you who have followed me will also sit upon twelve thrones, judging the twelve tribes of Israel.' (Matt. 19:28.) 'Judging' may mean here 'ruling over'.

18. 'By a single, uninterrupted and everlasting act the mind of a human being will be united with God in that state of beatitude' - Summa Theologiae, 1a 2ae. 3. 2 ad.4.

19. See his Enchiridion, chs. 112 and 113.

20. Aquinas wrote: "There would be no everlasting punishment of the souls of the damned if they were able to change their will for a better will ... The souls of the wicked will cleave unchangeably to the end which they themselves have chosen. (Summa Contra Gentiles 4.93 .2 and 5.)

21. See my Existence of God (second edition, Oxford University Press, 2004) and the much shorter 'popular' version of this, Is There a God? (revised edition, Oxford University Press, 2010), for arguments to the existence of God. See my 'popular' book Was Jesus God? (Oxford University Press, 2008) summarising arguments contained in several of my other books, in 
favour of the detailed Christian doctrines about the nature and actions of God and the doctrine that he will provide an after-life. See my book Responsibility and Atonement, Oxford University Press, 1989, especially chs. 11 and 12 for a fuller account of the doctrine of the after-life in Christian tradition. 